\title{
DANIELA KERN
}

\section{I!}

Mestiçagens na Arte Contemporânea Icleia Borsa Cattani 


\section{MESTIÇAGENS NA ARTE CONTEMPORÂNEA - ICLEIA BORSA CATTANI}

O livro Mestiçagens na arte contemporânea é o resultado do longo e pioneiro trabalho de pesquisa sobre mestiçagens em artes visuais desenvolvido pelo grupo de pesquisadores coordenado por Icleia Borsa Cattani, trabalho este que originou também - Colóquio Internacional Mestiçagens na Arte Contemporânea, ocorrido entre 5 e 7 de novembro de 2007, em Porto Alegre, e mostra homônima no MARGS.

Já no texto introdutório do livro, Poiéticas e poéticas da mestiçagem, Icleia Cattani inicia a delimitação do conceito de mestiçagem, ao apontar sua origem em áreas como etnologia, história e antropologia, e ao anunciar sua diferença essencial quando aplicado especificamente ao campo das artes.

Mestiçagens na arte contemporânea divide seus textos em quatro blocos. $O$ primeiro deles, Questões teóricas e conceituais, apresenta o mapeamento das possibilidades do conceito de mestiçagem nas artes visuais através dos artigos de Icleia Cattani, Mestiçagens na arte contemporânea: conceito e desdobramentos, e de Marc Jimenez, A estética como resistência, texto originalmente publicado no livro Vers une esthétique du métissage (2002), de Dominique Berthet. Icleia, avançando na definição do conceito de mestiçagem, em primeiro lugar o contrapõe aos conceitos de sincretismo e de hibridismo, para depois aproximá-lo do rizoma de Deleuze e Guattari e desdobrá-lo em várias problemáticas (deslocamento de sentido, apropriações e justaposições, desdobramentos e ambigüidades, proliferações e transversalidades, migrações, poiética/poética, u-topos). Marc Jimenez, a seu tempo, irá situar a mestiçagem em relação a outra gama de conceitos, como pós-modernidade, multiculturalismo e mundialização, defendendo uma autêntica e interativa estética mestiça que respeite as identidades culturais particulares.

Em Ressignificações da Modernidade, segundo bloco da obra, o conceito de mestiçagem permeará as análises de obras e eventos modernistas. Assim, Éliane Chiron, em Fonte testando Khôra: o tornar-se-lugar do objeto duchampiano, estende a mestiçagem tanto ao observador quanto ao lugar do objeto e do artista Duchamp; Dominique Berthet, em $O$ imprevisível resultado do reencontro, a partir da discussão das definições de mestiçagem formuladas por Roger Toumson e por Edouard Glissant nos anos noventa, considera a natureza do sexto sol asteca e o impacto da passagem de André Breton pelo Haiti; Mário Azevedo desvenda os "lugares da mestiçagem" em Os carnets de Torres Garcia, e Camila Schenkel, em Fotomontagem: desdobramentos de um processo centenário de mestiçagem, aborda a fotomontagem como "técnica mestiça". 
Proposições Poéticas, terceiro bloco do livro, destina-se às pesquisas voltadas à poética das obras acabadas lida sob a ótica da mestiçagem. É assim que Ana Carvalho, ao analisar obras de Vera Chaves Barcellos, propõe a instalação como modo de espacialização mestiço. Nara Cristina Santos persegue o conceito de mestiçagem na obra de Luciano Santos, enquanto Nadja de Carvalho Lamas identifica a mestiçagem nas apropriações de Schwanke. Se Viviane Rocha observa a mestiçagem nas performances pelo viés da diferença, Juliana Angeli retoma os procedimentos mestiços no levantamento do emprego contemporâneo do retrato fotográfico. Viviane Gil, por sua vez, atenta para possíveis procedimentos mestiços relacionados ao uso de vestes nas obras de Karin Lambrecht, enquanto Michael Kirschbaum discorre sobre a mestiçagem presente na adoção, por parte de artistas contemporâneos, de modelos teóricos de representação espacial.

O quatro e último bloco da obra, Reflexões Poiéticas, dedica-se aos estudos sobre mestiçagem que se aplicam à poiética contemporânea, ou seja, à filosofia das condutas e das criações artísticas. Bernard Paquet relata, neste segmento, sua experiência interativa (e, logo, potencialmente mestiça) com o Gerador Poiético; Alfredo Nicolaiewsky apresenta a pesquisa $\mathrm{Da}$ ordem do enigma, que resultou em uma série de obras que adentram o território formal da mestiçagem; Maristela Salvatori observa a "mestiçagem" contemporânea de uma velha tecnologia como a gravura em metal, com uma tecnologia novíssima, como a criação digital de imagens; Maria Lucia Cattani faz a contagem regressiva da preparação mestiça (uma vez que mescla gravura e questões pictóricas) da obra que expôs na 5a. Bienal do Mercosul, em 1997; Paulo Gomes desvela a preparação de seu livro de artista Simenon/Maigret (2002/2003); Marcelo Gobatto identifica em sua instalação Palavra proibida a mestiçagem com as tensões entre discursos libertários e discursos autoritários acionados pela obra; Lenir de Miranda, enfim, põe a nu a própria poética/poiética mestiça de suas obras.

Muito bem estruturada pela organizadora, Icleia Cattani, e belamente editada pela Editora da UFRGS, a obra Mestiçagens na arte contemporânea sem dúvida contribui, de modo importante, para o incremento da pesquisa e da produção teórica original em artes visuais no país.

\section{REFERÊNCIA BIBLIOGRÁFICA}

CATTANI, Icleia Borsa (Org.). Mestiçagens na arte contemporânea. Porto Alegre: Editora da UFRGS, 2007.<smiles>[CH]1C=CC1</smiles>

DANIELA KERN é Dra. em Letras pela PUCRS, Pesquisadora PRODOCCAPES e Professora Colaboradora do PPG Artes Visuais - IA - UFRGS. É tradutora dos livros A distinção, de Pierre Bourdieu, $\mathrm{O} 0$ mercado da arte, de Raymonde Moulin. 